\title{
ASSESSING SEDIMENT REGIME ALTERATION OF THE LOWER DRAVA RIVER
}

Scientific paper / Znanstveni rad

Senlin Zhu

(Received: 21 April 2019; accepted: 30 September 2019)

State Key Laboratory of Hydrology-Water resources and Hydraulic Engineering, Nanjing Hydraulic Research Institute, China

Ognjen Bonacci

University of Split, Faculty of Civil Engineering, Architecture and Geodesy, Full Professor

Corresponding author: obonacci@gradst.hr

Dijana Oskoruš

Meteorological and Hydrological Service, PhD.

\begin{abstract}
Alterations to the sediment regime of the lower Drava River were assessed using the rescaled adjusted partial sums (RAPS) method and possible causes of these changes are discussed in this paper. The sudden alteration to sediment regime and the sharp decreases of suspended sediment concentration (SSC) at the two gauging stations in the lower Drava River began in the 1980s. Suspended sediment load decreased about $65 \%$

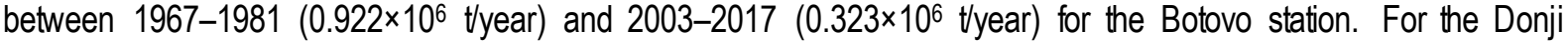

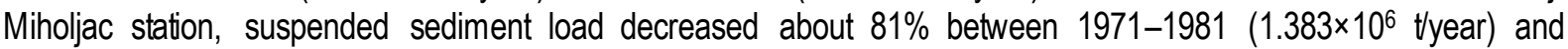
2007-2017 (0.263× $10^{6}$ tyear). The construction and operation of reservoirs were the main reasons for these sharp alterations. SSC and flow discharge (Q) relationships were assessed by proposing a new form of a sediment rating curve (SRC). Compared with the traditional SRC approach, the new form of the SRC can better capture seasonal dynamics of SSC at daily and monthly time-scales.
\end{abstract}

Keywords: sediment load; flow discharge; reservoir operation; sediment rating curve; Drava River (Croatia)

\section{PROCJENA PROMJENA REŽIMA SUSPENDIRANOG NANOSA NA DONJEM TOKU RIJEKE DRAVE}

Sažetak: Promjene režima suspendiranog nanosa na donjem toku rijeke Drave izučavani su primjenom metode RAPS (Rescaled Adjusted Partial Sums). Rezultati analize pokazali su da je do nagle promjene režima nanosa i smanjenja koncentracije suspendiranog nanosa (SSC) na dvije vodomjerne postaje na rijeci Dravi došlo početkom osamdeseth godina dvadesetog stoljeća. Pronos suspendiranog nanosa na postaji Botovo smanjen je u razdoblju 2003. - 2017. $\left(0.323 \times 10^{6} \mathrm{tgod}\right)$ u odnosu na prethodno razdoblje 1967. - 1981. $\left(0.922 \times 10^{6} \mathrm{tgod}\right)$ za oko $65 \%$. Pronos suspendiranog nanosa na postaji Donji Miholjac smanjen je u razdoblju 2007. - 2017. (0.263 $\left.\times 10^{6} \mathrm{tgod}\right) \mathrm{u}$ odnosu na prethodno razdoblje 1971. - 1981. (1.383 × $10^{6}$ tgod) za čak oko $81 \%$. Glavni razlog smanjenja je izgradnja akumulacija za potrebe rada tri hidroelektrane u Hrvatskoj. Odnos između SSC i protoka (Q) korišten je za izradu krivulje pronosa suspendiranog nanosa (SRC) u novim uvjetima. Analize ukazuju da su SRC u novim uvjetima osjetjivije na sezonsku dinamiku od onih u prethodnom razdoblju.

Ključne riječi: pronos suspendiranog nanosa; protok vode; akumulacija; krivulja pronosa suspendiranog nanosa; Rijeka Drava (Hrvatska) 


\section{INTRODUCTION}

Suspended sediment concentration (SSC) and sediment load are important characteristics in river geomorphology and are closely related to the geological settings of river systems [1-3]. Since suspended sediment carries contaminants, including phosphorus and heavy metals [4,5], it affects the water quality of rivers [6]. Additionally, suspended sediment impacts light attenuation in waterbodies, which further influences the development of aquatic communities [7-9]. Thus, the assessment of SSC and sediment load is of great significance for sustainable management of river systems.

In the past few decades, with the impacts of anthropogenic activities, including damming [10-13], land use change [14, 15], and climate change [11, 14], sediment regime in many rivers has been dramatically altered. For example, Dai et al. [16] found that dam construction and bank reinforcements along the Yangte River resulted in a decline in SSC delivered by the Yangze River into the East China Sea. The change of sediment regime in rivers may cause serious consequences, including the prevention of burrowing benthos from finding suitable habitats [17] and negative impacts on delta evolution [18]. Therefore, understanding how sediment regime has changed under complex conditions is very important.

The Drava River is one of the largest tributaries of the Danube River. It originates in Italy, crosses Austria, Slovenia, Hungary and Croatia, and finally joins the Danube River downstream of Osijek, Croatia (Figure 1). Previously, Bonacci et al. [19], Bonacci and Oskoruš [20], and Tadić and Brleković [21] analyzed the hydrological regime of the lower Drava River. Additionally, Bonacci and Oskoruš [22], and Tamás [23] analyzed human impacts on water regime in the lower Drava River, and sediment transport in the Drava River, respectively. In the current study, long term observation data were used to assess sediment regime in the lower Drava River, which allows explanation of the processes of river evolution. Furthermore, models were developed to estimate SSC and flow discharge $(Q)$ relationships at different time-scales; such relationships can be used to inform river management and for designing restoration. Since the Drava River is a large tributary of the Danube River, the results in this study can also be used to inform river management in the Danube River basin.

\section{MATERIALS AND METHODS}

\subsection{Study area}

In this study, the lower Drava River, between Slovenian and Croatian state boundaries, was evaluated. Daily $Q$ and SSC from two gauging stations (Botovo and Donji Miholjac) were analyzed (Figure 1; data provided by the Croatian Meteorological and Hydrological Service). SSC data were obtained from daily water samples taken from one point (close to the riverbed in water gauging profile). These samples were taken at the same hour every day. Because both sampling sites (Botovo $28 \mathrm{~km}$; Donji Miholjac $178 \mathrm{~km}$ ) are far from the downstream reservoir Dubrava, possible effects of the operation of Hydro Electric Power Plants (HEPP was minimized. Each sample was poured through a $0.45 \mu \mathrm{m}$ thick filter paper (320 mm diameter Munktell filter paper). Daily $Q$ was calculated from hourly values based on hourly measurements of water level (WL). The WL-Q RK method was used for hourly calculations of $Q$. The defined RK varied over time due to morphological changes of the river bed. Consequently, many rating curves were calculated, but only two RK examples per station are presented herein: the newest one, and one in 2009 (Figure 2). The main characteristics of the two gauging stations, including distance from the river mouth, basin area, elevation and the available data period are summarized in Table 1. Table 2 presents the detailed information of three hydroelectric power plants (HEPP) constructed in the lower Drava River. Figure 3 presents the daily SSC and $Q$ time series for the two gauging stations. Table 3 summarizes the statistics of the daily SSC and Q. Q of the two stations generally followed the same temporal pattern with Botovo station having higher extreme values in the flood season (Table 3). Difference of annual mean value of $Q$ between the two stations was small since there were no large tributaries between Botovo and Donji Miholjac. The standard deviations of SSC data were much greater than the averages, which indicates a very big scatter (Table 3 ) or can also indicate incoherence of the sampling methods used. SSC of the two stations presented large difference, especially during the flood season (Figure 3). 


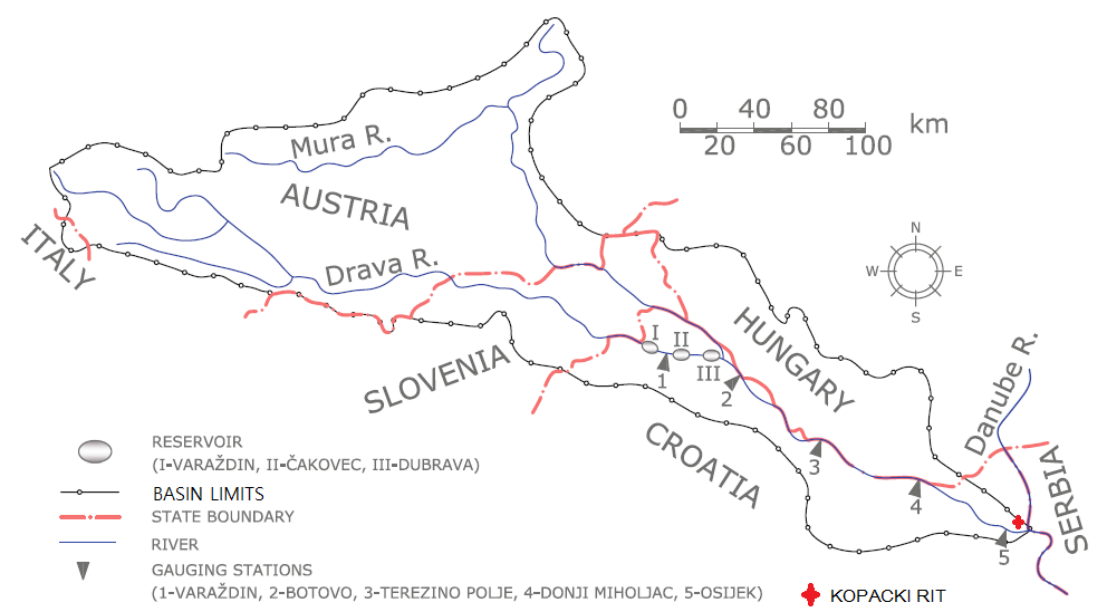

Figure 1 Location maps of the Drava River, with positions of five gauging stations and three HEPP (IHEPP Varaždin; II-HEPP Čakovec; III-HEPP Dubrava) [20]
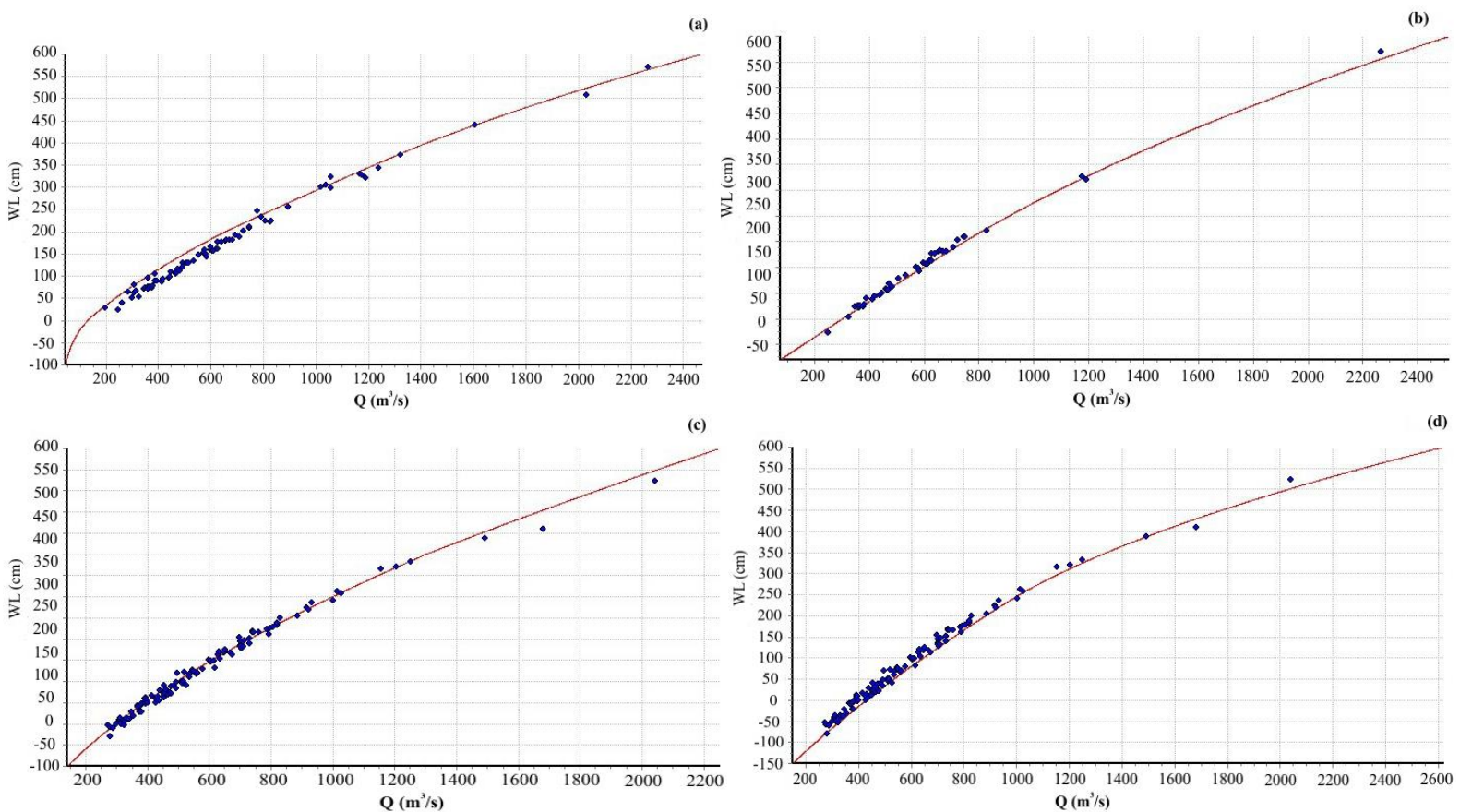

Figure 2 The WL-Q RK relationships for each station: (a) Botovo 2009, (b) Botovo 2017-2019, (c) Donji Miholjac 2009, (d) Donji Miholjac 2017-2019

Table 1 Main characteristics of the two gauging stations in the lower Drava River

\begin{tabular}{ccccc}
\hline Station name & Distance from the mouth $(\mathbf{k m})$ & Basin area $\left(\mathbf{k m}^{2}\right)$ & Elevation $(\mathbf{m}$ a. s. I.) & Observation period \\
\hline Botovo & 227 & 31.038 & 121.55 & $1967-2017$ \\
Donji Miholjac & 80.5 & 37.142 & 88.57 & $1971-2017$ \\
\hline
\end{tabular}

Table 2 Main characteristics of the three hydroelectric power plants (HEPP) in the lower Drava River

\begin{tabular}{cccc}
\hline HEPP & Varaždin & Čakovec & Dubrava \\
\hline Start of operation $($ year $)$ & 1975 & 1982 & 1989 \\
Installed discharge $\left(\mathrm{m}^{3} / \mathrm{s}\right)$ & 450 & 500 & 500 \\
Mean power generation $(\mathrm{GWh} /$ year $)$ & 476 & 400 & 385 \\
Reservoir volume $\left(10^{6} \mathrm{~m}^{3}\right)$ & 8.0 & 51.0 & 93.5 \\
Reservoir water surface $\left(\mathrm{km}^{2}\right)$ & 3.0 & 10.5 & 16.6 \\
Maximum water level in the reservoir $(\mathrm{m}$ a. s. I.) & 191.0 & 168.0 & 149.6 \\
\hline
\end{tabular}

Zhu, S, Bonacci, O, Oskoruš, D 
Table 3 Summary statistics of the daily data sets

\begin{tabular}{ccccc}
\hline \multirow{2}{*}{ Statistical parameters } & \multicolumn{2}{c}{ Botovo } & \multicolumn{2}{c}{ Donji Miholjac } \\
\cline { 2 - 5 } & $\mathbf{Q}\left(\mathbf{m}^{3} / \mathbf{s}\right)$ & $\mathbf{S S C}(\mathbf{m g} / \mathbf{L})$ & $\mathbf{Q}\left(\mathbf{m}^{3 /} \mathbf{s}\right)$ & $\mathbf{S S C}(\mathbf{m g} / \mathbf{L})$ \\
\hline$X_{\text {mean }}$ & 490.43 & 23.74 & 513.22 & 29.33 \\
$X_{\max }$ & 2630 & 701 & 2281 & 891 \\
$X_{\min }$ & 103 & 0.03 & 166 & 0.01 \\
$S_{X}$ & 241.66 & 31.39 & 236.10 & 40.34 \\
$C_{V}$ & 0.49 & 1.32 & 0.46 & 1.38 \\
\hline
\end{tabular}

Note: $X_{\text {mean }}$, mean; $X_{\max }$, maximum; $X_{\min }$, minimum; $S x$, standard deviation; $C v$, coefficient of variation

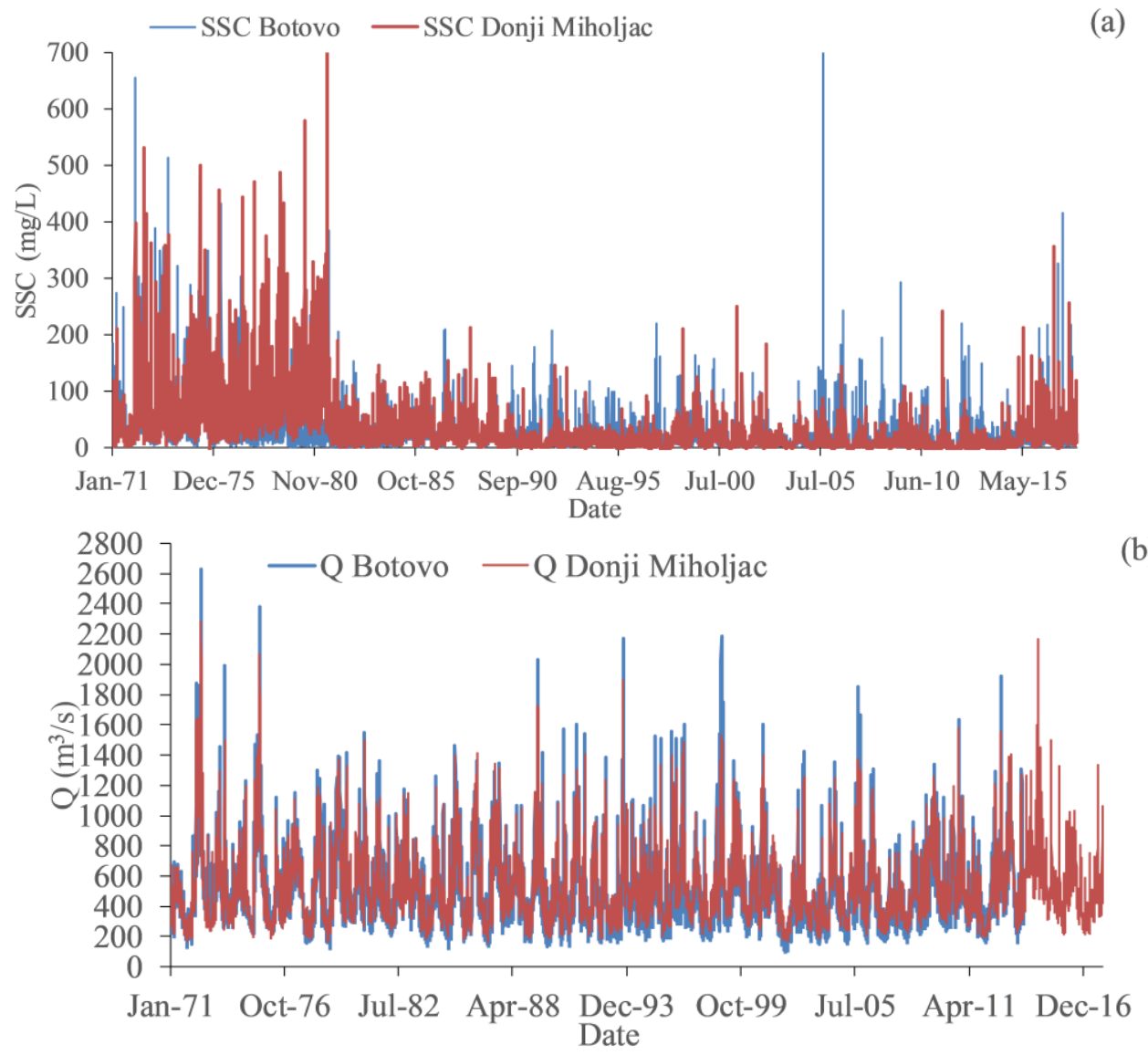

Figure 3 Time series of daily SSC and Q for the two gauging stations: (a) SSC and (b) Q

\subsection{Methods}

To detect and quantify trends and fluctuations in sampled time series, the widely used rescaled adjusted partial sums (RAPS) method [20, 24-26] was employed in this study. The RAPS method can highlight trends, shifts, data clustering, irregular fluctuations, and periodicities in the time series [24], which can be defined by:

$R A P S_{i}=\sum_{n=1}^{i} \frac{T_{n}-T_{m}}{S_{T}}$

where $T_{m}$ is the mean value of the time series, $S_{T}$ is the standard deviation, $T_{n}$ is the value of a sample, and $n=1,2 \ldots, N, N$ is the number of values in the time series.

To quantitatively analyze SSC-Q relations at daily and monthly time-scales, the widely used sediment rating curve (SRC) was employed. The SRC was used to regress sediment load, in particular SSC in river systems, from $Q$ [27-30]. Normally, a power equation is used:

$S S C=a Q^{b}$

Zhu, S, Bonacci, O, Oskoruš, D 
where $a$ and $b$ are regression coefficients. In the SRC method, the coefficients $a$ and $b$ are constants without physical significance; however, some researchers still attribute meaning to them, relating them to the severity of erosion and transport processes [27, 30].

\subsection{Model performance index}

Model performances were evaluated using the following two indicators: the coefficient of correlation $(R)$ and the root mean-squared error (RMSE):

$$
\begin{aligned}
& R=\left[\frac{\frac{1}{n} \sum_{i=1}^{n}\left(\mathrm{O}_{i}-\mathrm{O}_{m}\right)\left(\mathrm{P}_{i}-\mathrm{P}_{m}\right)}{\sqrt{\frac{1}{n} \sum_{i=1}^{n}\left(\mathrm{O}_{i}-\mathrm{O}_{m}\right)^{2}} \sqrt{\frac{1}{n} \sum_{i=1}^{n}\left(\mathrm{P}_{i}-\mathrm{P}_{m}\right)^{2}}}\right] \\
& R M S E=\sqrt{\frac{1}{n} \sum_{i=1}^{n}\left(\mathrm{O}_{i}-\mathrm{P}_{i}\right)^{2}}
\end{aligned}
$$

where $n$ is the number of data samples, $O_{i}$ and $P_{i}$ are the observed and predicted values. $O_{m}$ and $P_{m}$ are the average values of $\mathrm{O}_{i}$ and $\mathrm{P}_{\mathrm{i}}$.

\section{RESULTS AND DISCUSSION}

\subsection{Variations of Q, SSC, water level, and suspended sediment load}

Figure 4 presents temporal variations of RAPS values for annual averaged Q, SSC and the amount of suspended sediment at the two gauging stations. For Botovo station, a sharp drop of $Q, S S C$ and suspended sediment load began from 1982 (Figure 4(a)), thereby dividing the time series into two sub-periods: the first from 1967 to 1981 , and the second from 1982 to 2017. Interestingly, with the decrease of Q, SSC and suspended sediment load, the water level (WL) began to increase (Figure 4(a)), which clearly indicates a change to the river bed [22]. Figure 5 shows the relations of $Q$ and $W L$ at Botovo station for the two sub-periods, 1967-1981 and 1982-2017. Before 1982, WL was linearly correlated with $Q\left(R^{2}=0.96\right)$, indicating a stable river bed during this period (Figure $\left.5(a)\right)$. The linear correlations between $W L$ and $Q$ became weak $\left(R^{2}=0.50\right)$ for the second sub-period. Seasonal dynamics of SSC and Q were further assessed through the climatological year, which was defined by averaging for each day of the year all measurements available over the observation period for that specific day [31]. For the two sub-periods, peak values of SSC and Q were both apparent during the summer period (Figure 6). In the first sub-period (19671981), SSC correlated well with $Q\left(R^{2}=0.80\right)$ with a power function (Equation (2)). However, for the second subperiod (1982-2017), the correlation between $S S C$ and $Q$ became weak $\left(R^{2}=0.62\right)$. Monthly averaged $S S C$ and $Q$ in the period 1967-1981 exhibited similar seasonal characteristics (Figure 7). However, monthly averaged SSC and $Q$ in the period 1982-2017 exhibited different seasonal patterns after August (Figure 7). Notably, the average monthly mean SSC value in the flood season during the period 1982-2017 was even smaller than that in the dry season during the period 1967-1981.

For Donji Miholjac station, a sharp decrease of SSC and suspended sediment load also began in 1982 (Figure 4(b)), dividing the time series into two sub-periods: the first from 1971 to 1981, and the second from 1982 to 2017. However, $Q$ and WL did not exhibit a clear trend. For Donji Miholjac station, WL was linearly correlated with $Q$ $\left(R^{2}=0.95\right)$, indicating a stable river bed in these 47 years (Figure 8). When expressed on a climatological year, both SSC and $Q$ were concentrated in the summer period during the flood season (Figure 9). Additionally, for the first sub-period (1971-1981), high SSC values were observed in spring and SSC was poorly correlated with $Q\left(R^{2}=0.38\right)$ with a power function (Equation (2)). However, for the second sub-period (1982-2017), the correlation between SSC and $Q$ became stronger $\left(R^{2}=0.56\right)$. Monthly averaged SSC in both periods exhibited seasonal characteristics, following the pattern of $Q$ (Figure 10). Notably, the average monthly mean SSC value in the flood season during the period 1982-2017 was far smaller than that in the dry season during the period 1971-1981. 


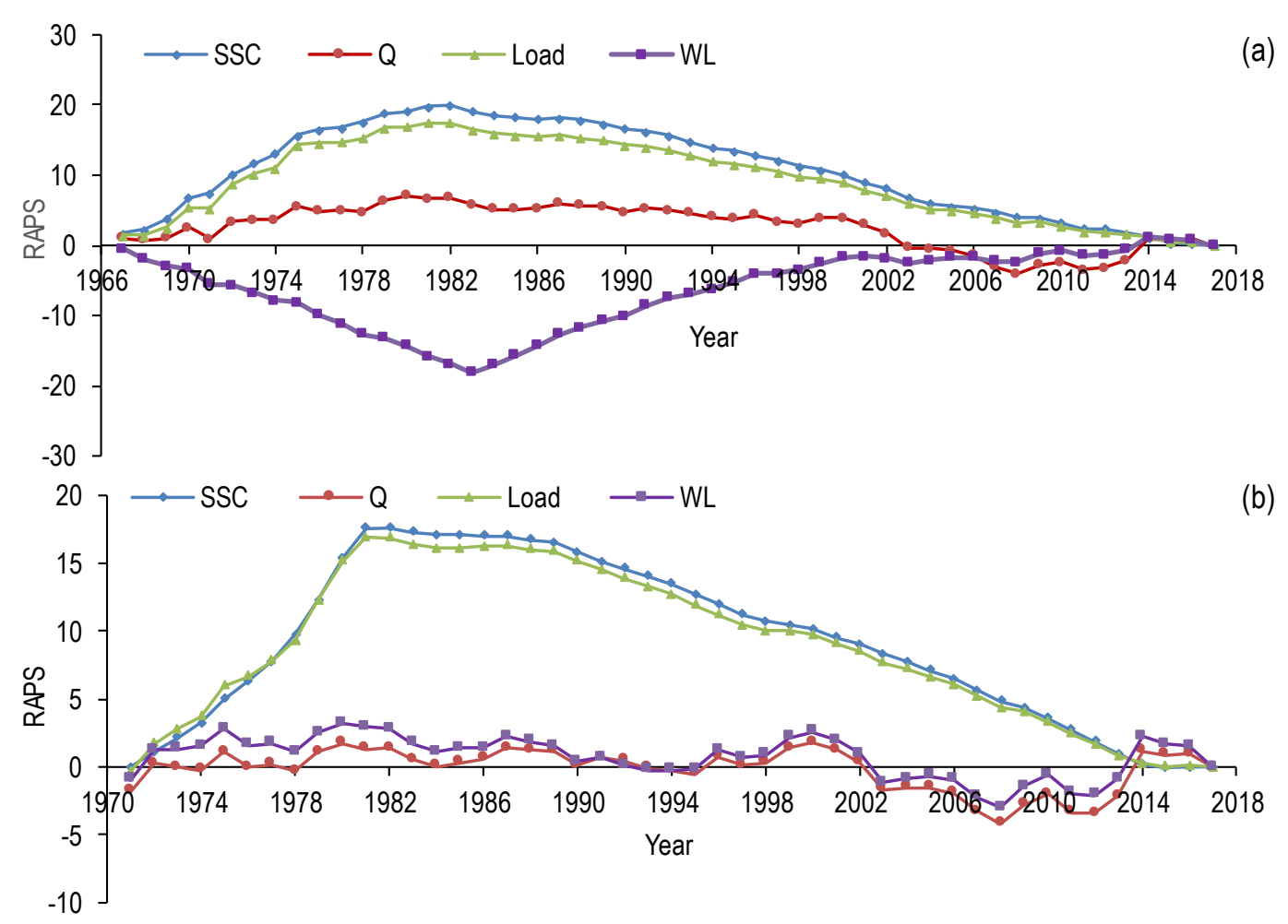

Figure 4 Temporal variations of RAPS values for annual averaged Q, SSC, WL, and suspended sediment load at the two gauging stations: (a) Botovo and (b) Donji Miholjac

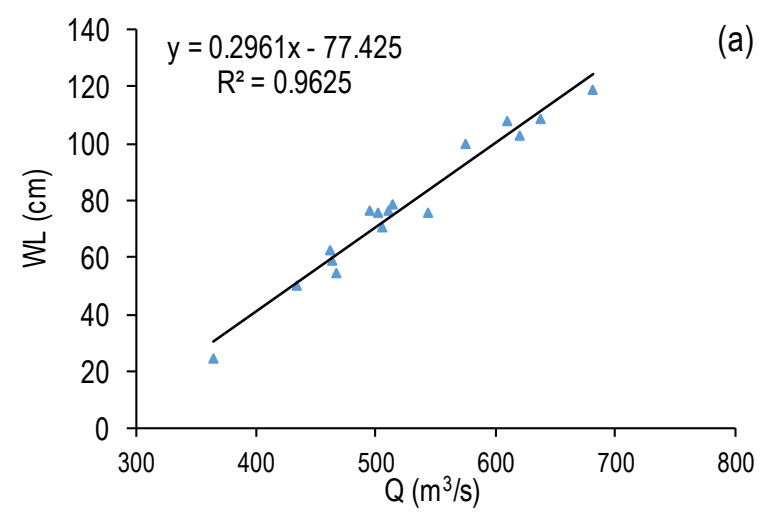

(a)

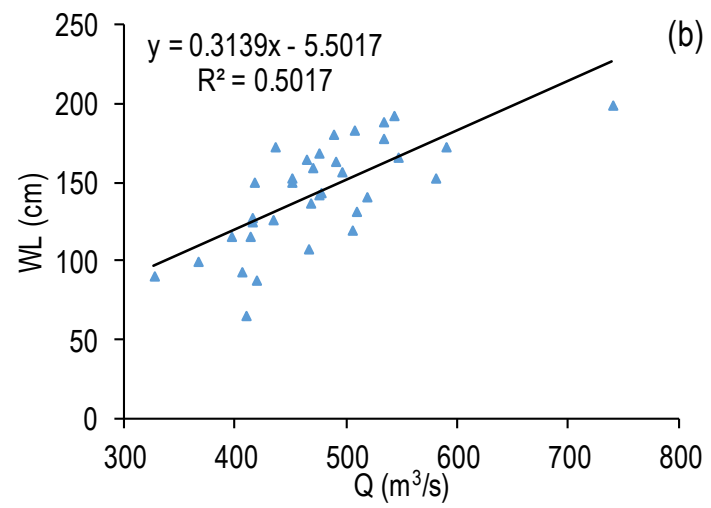

Figure 5 Flow discharge and water level relations at Botovo station: (a) 1967-1981, (b) 1982-2017

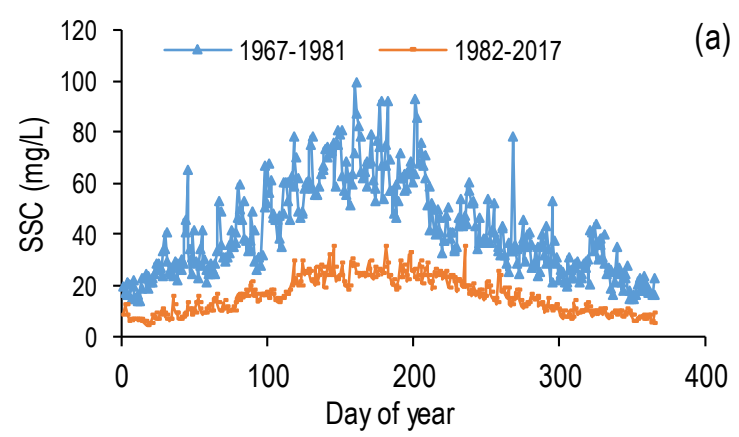

(a)

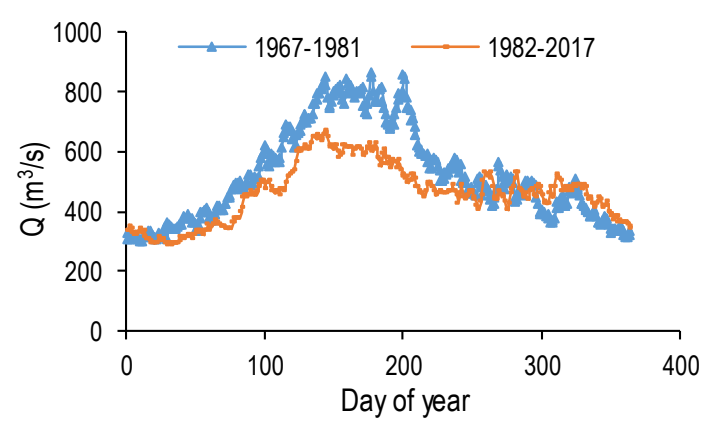

(b)

Figure 6 Seasonal variations of daily averaged SSC (a) and Q (b) at Botovo station for the climatological year

Zhu, S, Bonacci, O, Oskoruš, D 

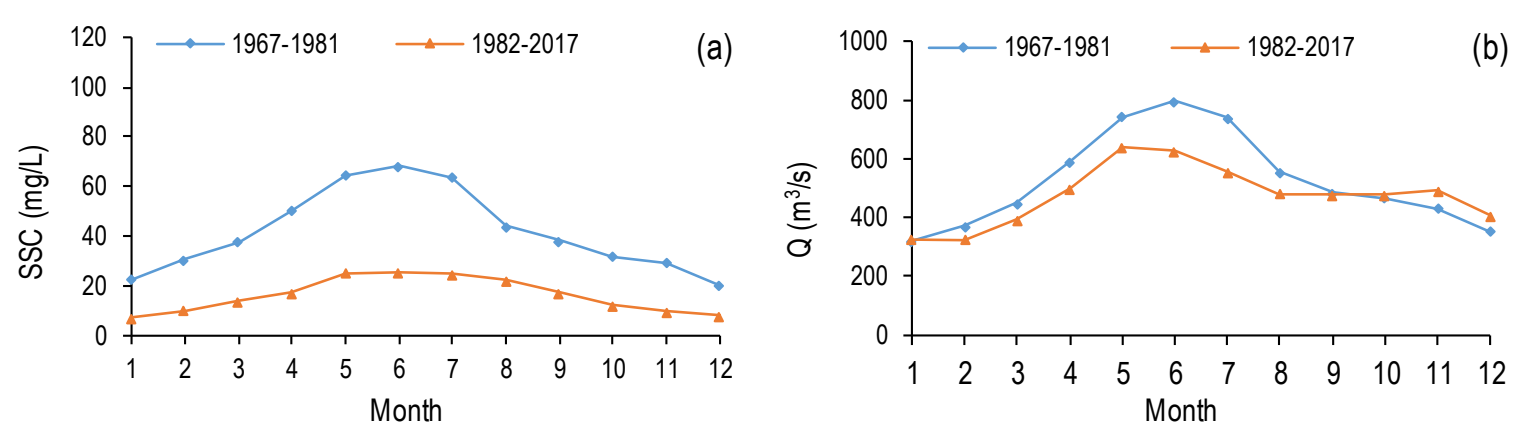

Figure 7 Monthly averaged SSC (a) and $Q(b)$ at Botovo station

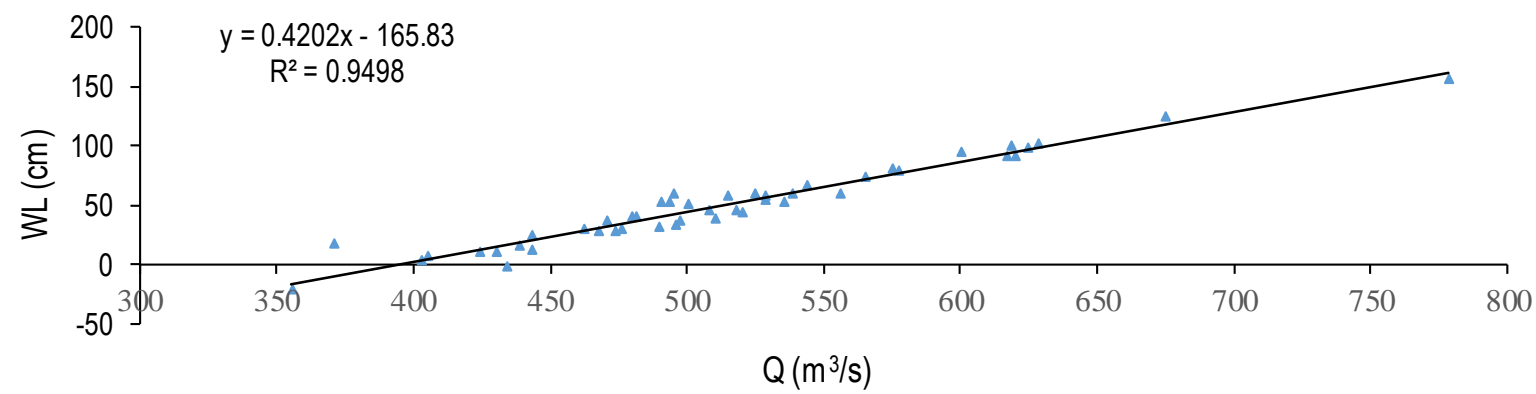

Figure 8 Flow discharge and water level relationship at Donji Miholjac station
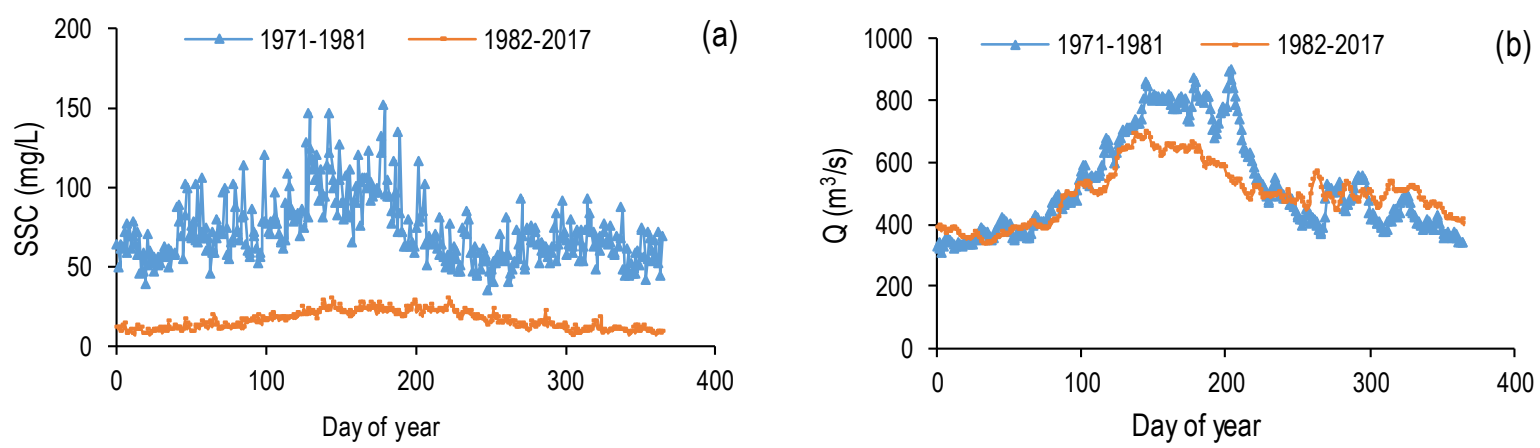

Figure 9 Seasonal variations of daily averaged SSC (a) and Q (b) at Donji Miholjac station for the climatological year

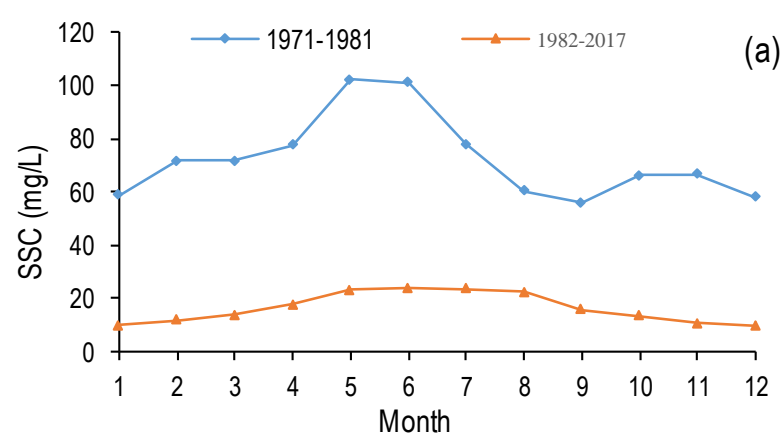

(a)

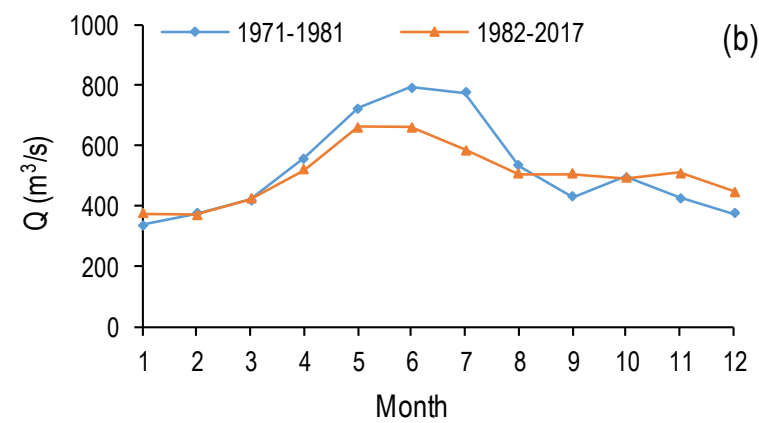

Figure 10 Monthly averaged SSC (a) and Q (b) at Donji Miholjac station

Zhu, S, Bonacci, O, Oskoruš, D 
The sudden alteration of sediment regime and the sharp decreases of SSC at the two gauging stations in the lower Drava River began from the 1980s. Suspended sediment load decreased about $65 \%$ from 1967-1981

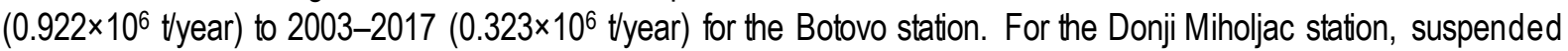

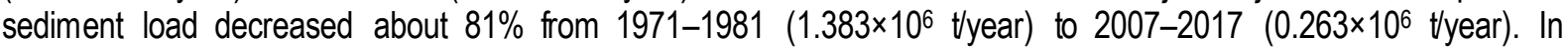
previous studies, in the time series of many climate-related variables (e.g. Q, WL, and water temperature), a rather sudden change, or an inflection point, had been observed around the mid-1980s [19-21, 32-35]. Results of the current study further confirmed this conclusion. Based on the operating times of the three reservoirs in the lower Drava River (Table 2), it can be concluded that the sharp decreases of SSC and sediment load are greatly impacted by the construction and operation of reservoirs. In addition, the management of about $80 \mathrm{~km}$ of the lower Drava River bed and the adjacent catchment from the 1980s by "river training" measures, also plays an important role [22]. Regional climate change as well as other anthropogenic influences (i.e. material excavation) could be additional reasons for this decreasing trend [20]. Kopački Rit is located at the confluence of the Drava River and the Danube River. It is one of the most important and well-preserved natural wettands in Europe. Compared to the wettand area of 37000 ha that existed in the 18th century, there has been a substantial reduction of flood retention capacity along the left bank, downstream to Osijek, which may have been caused by the regulation works employed to deal with the sharp decreases of SSC and sediment load from the Drava River to the Danube River [22]. This issue may bring serious consequences, which should be considered.

\subsection{Modeling of SSC and Q relationships}

Figure 11 shows the correlation coefficients between monthly averaged SSC and Q for each year at the two gauging stations. For Botovo station, in $84 \%$ of cases, the correlation coefficients between monthly averaged SSC and $Q$ in each year exceeded 0.6 , which indicates that using $Q$ for regression of monthly averaged SSC is generally fine at this station. However, at the Donji Miholjac station, only $66 \%$ of the correlation coefficients between monthly averaged SSC and $Q$ in each year exceeded 0.6 , and in some years, the correlation coefficients were lower than 0.0 , indicating that using $Q$ for regression of monthly averaged SSC may not be appropriate at this station. The difference is probably linked with the spatial and temporal dynamics of the anthropic pressures in the river channel and the associated channel processes. The management of about $80 \mathrm{~km}$ of the lower Drava River bed and the adjacent catchment by "river training" measures [22] greatly altered the sediment regime at the Donji Miholjac station. Using the traditional SRC method, the regression formulae were derived for each gauging station at monthly intervals, to give:

$$
\mathrm{SSC}=0.006 \mathrm{Q}^{1.34} \mathrm{R}=0.65 \quad \mathrm{RMSE}=15.69 \text { (Botovo) }
$$

$\mathrm{SSC}=0.189 \mathrm{Q}^{0.89} \mathrm{R}=0.29 \mathrm{RMSE}=29.70$ (Donji Miholjac)

The result of Botovo station was acceptable $(R=0.65$, RMSE $=15.69 \mathrm{mg} / \mathrm{L})$. However, for Donji Miholjac station, the result was poor $(\mathrm{R}=0.29, \mathrm{RMSE}=29.70 \mathrm{mg} / \mathrm{L})$. In order to improve modeling performance, SSC was regressed using the SSC from the previous month (SSCt-1), and $Q$ in the same month ( $\left.Q_{t}\right)$. The results of the new regression were far better, with larger $R$ and lower RMSE values. For both stations, $R$ values exceeded 0.8 and RMSE values decreased significantly, especially for the Donji Miholjac station:

$$
\begin{aligned}
& \mathrm{SSC}_{t}=0.541 \mathrm{SSC}_{\mathrm{t}-1}+0.0005 \mathrm{Q}_{t}^{1.6} \quad \mathrm{R}=0.80 \quad \mathrm{RMSE}=12.32 \text { (Botovo) } \\
& \mathrm{SSC}_{t}=0.836 \mathrm{SSC}_{\mathrm{t}-1}+0.0005 \mathrm{Q}_{t}^{1.453} \quad \mathrm{R}=0.866 \quad \mathrm{RMSE}=15.52 \text { (Donji Miholjac) }
\end{aligned}
$$



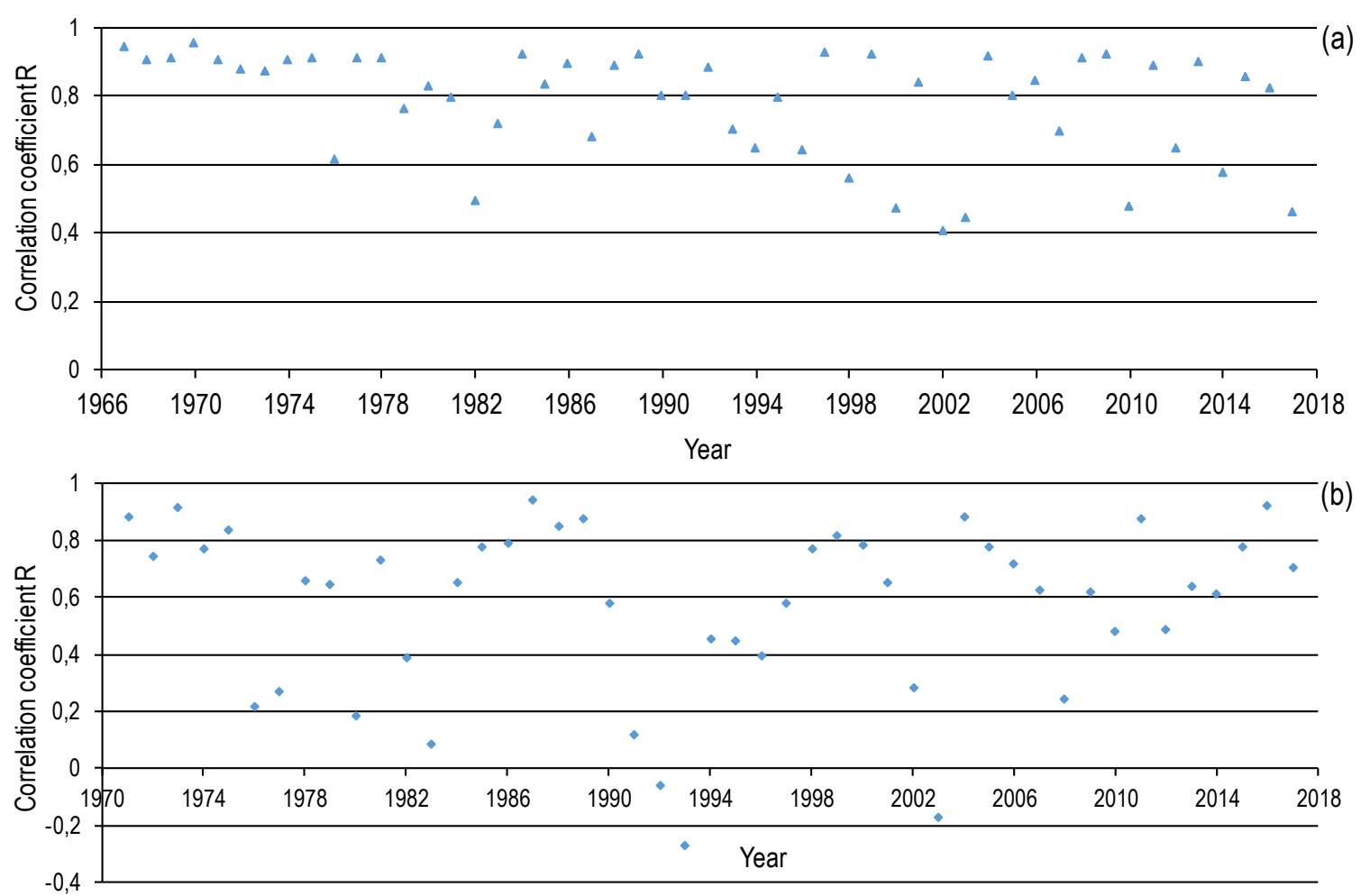

Figure 11 Correlation coefficients of the regression of monthly averaged SSC and Q for each year at the two gauging stations: (a) Botovo and (b) Donji Miholjac

Using the traditional SRC method, regression formulas were derived for each gauging station at a daily timescale:

$\mathrm{SSC}=0.053 \mathrm{Q}^{0.993} \mathrm{R}=0.54 \quad \mathrm{RMSE}=26.87$ (Botovo)

$\mathrm{SSC}=0.153 \mathrm{Q}^{0.843} \mathrm{R}=0.27 \quad \mathrm{RMSE}=38.80$ (Donji Miholjac)

The results of both stations were poor and consequently SSC was regressed using the SSC from the previous day $\left(S_{S C} C_{t-1}\right)$, and $Q$ in the same day $\left(Q_{t}\right)$. The results of the new regression were better, with higher $R$ values and lower RMSE values. For both stations, $\mathrm{R}$ values exceeded 0.7 . Figure 12 presents the comparison of modeled and observed SSC values for 2015-2017 at the two gauging stations. The new SRC formula captured the seasonal dynamics of SSC, especially for lower SSC values. However, the new SRC formula failed to accurately model extreme SSC values (Figure 8), which has been a general problem for various models [28, 36-38]. Compared with the traditional SRC method, which employs only $Q$ to obtain SSC, the new SRC formula is more stationary since it considered SSC values from the previous day or month. The poor performance of the traditional SRC method also indicated that the power function in Equation (2) may not be applicable for all river stations, which has also been discussed in [38].

$$
\begin{array}{lll}
\mathrm{SSC}_{t}=0.585 \mathrm{SSC}_{\mathrm{t}-1}+0.0005 \mathrm{Q}_{t}^{1.22} & \mathrm{R}=0.73 & \mathrm{RMSE}=21.54 \text { (Botovo) } \\
\mathrm{SSC}_{t}=0.71 \mathrm{SSC}_{\mathrm{t}-1}+0.0422 \mathrm{Q}_{t}^{0.852} & \mathrm{R}=0.74 & \mathrm{RMSE}=27.30 \text { (Donji Miholjac) }
\end{array}
$$



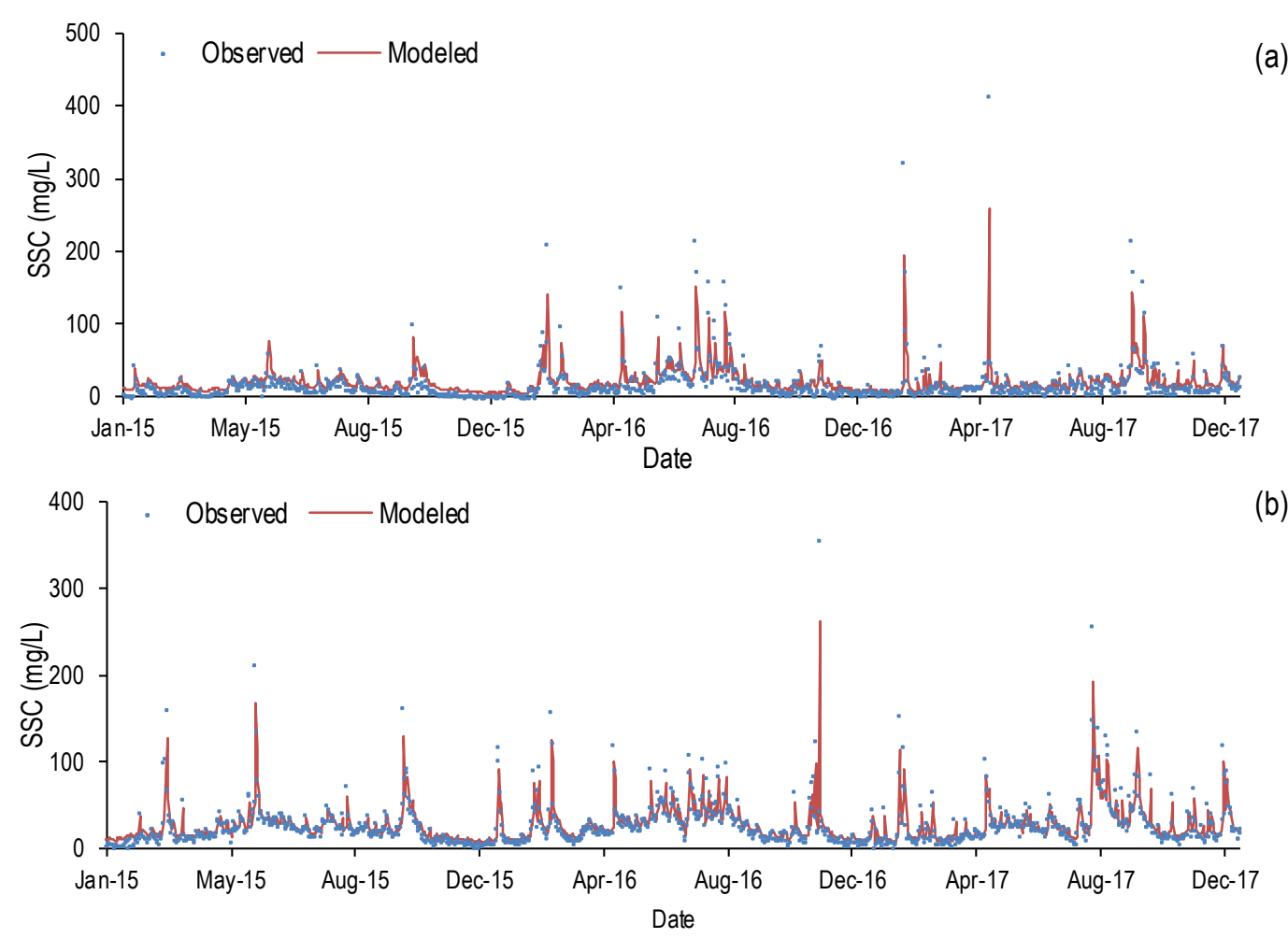

(b)

Figure 12 Comparison of modeled and observed SSC values for the time period of 2015-2017 at the two gauging stations: (a) Botovo and (b) Donji Miholjac

\section{CONCLUSIONS}

Using the RAPS method, the alteration to the sediment regime of the lower Drava River was assessed and its possible causes were discussed. Suspended sediment load decreased about $65 \%$ between $1967-1981\left(0.922 \times 10^{6}\right.$

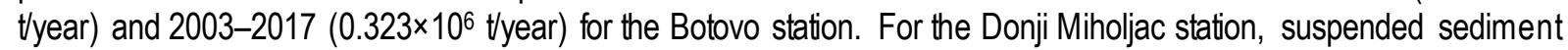

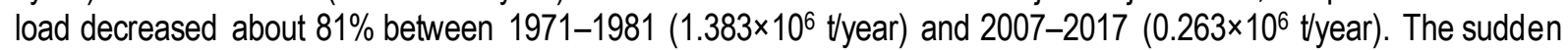
alteration of sediment regime and the sharp decreases of SSC at the two gauging stations began from the 1980s. This indicates that the change was mainly caused by the construction and operation of reservoirs, and the implementation of river training measures. The SSC-Q relationships were assessed by a new formulation of the SRC. Compared with the traditional SRC approach, the new form of SRC performed far better, with higher $R$ values and lower RMSE values, and was able to better capture seasonal dynamics of SSC at daily and monthly timescales. The results in this study can be used in designing river management and rehabilitation measures for the Drava River.

While SSCt was regressed from $S S_{t-1}, S_{S C}$, ..., as well as $Q_{t}, Q_{t-1}, Q_{t-2}$ using Excel Solver, modelling accuracy was not improved. Therefore, the best form is presented in this paper.

Acknowledgements: The Croatian Meteorological and Hydrological Service provided the suspended sediment, river flow discharge, and water level data used in this study. This work was jointly funded by the National Key R\&D Program of China (2018YFC0407203, 2016YFC0401506), China Postdoctoral Science Foundation (2018M640499), and the research project from Nanjing Hydraulic Research Institute (Y118009).

\section{References}

[1] Saito, Y.; Wei, H.L.; Zhou, Y.Q.; Nishimara, A.; Sato, Y.; Yokta, S. 2000: Delta propagation and chenier formation in the Huanghe (Yellow River) delta, China. Journal of Asian Earth Sciences, 18, pp. 489-497. 
[2] Falcini, F.; Piliouras, A.; Garra, R.; Guerin, A.; Jerolmack, D.J.; Rowland, J.; Paola, C. 2014: Hydrodynamic and suspended sediment transport controls on river mouth morphology. Journal of Geophysical Research: Earth Surface, 119 (1), pp. 1-11. https://doi.org/10.1002/2013JF002831

[3] Mayerle, R.; Narayanan, R.; Etri, T.; Wahab, A.K.A. 2015: A case study of sediment transport in the Paranagua Estuary complex in Brazil. Ocean Engineering, 106, pp. 161-174.

[4] Walling, D.E. 2005: Tracing suspended sediment sources in catchments and river systems. Science of the Total Environment, 344 (1-3), pp. 159-184. https://doi.org/10.1016/j.scitotenv.2005.02.011

[5] Schoellhamer, D.H.; Mumley, T.E.; Leatherbarrow, J.E. 2007: Suspended sediment and sediment-associated contaminants in San Francisco Bay. Environmental Research, 105 (1), pp. 119-131. https://doi.org/10.1016/j.envres.2007.02.002

[6] Somura, H.; Takeda, I.; Arnold, J.G.; Mori, Y.; Jeong, J.; Kannan, N.; Hoffman, D. 2012: Impact of suspended sediment and nutrient loading from land uses against water quality in the Hii River basin, Japan Journal of Hydrology, 450-451, pp. 25-35. https://doi.org/10.1016/j.jhydrol.2012.05.032

[7] Aumack, C.F.; Dunton, K.H.; Burd, A.B.; Funk, D.W.; Maffione, R.A. 2007: Linking light attenuation and suspended sediment loading to benthic productivity within an Arctic kelp-bed community. Journal of Phycology, 43 (5), pp. 853-863. https://doi.org/10.1111/j.1529-8817.2007.00383.x

[8] Bessell-Browne, P.; Negri, A.P.; Fisher, R.; Clode, P.L.; Duckworth, A.; Jones, R. 2017: Impacts of turbidity on corals: The relative importance of light limitation and suspended sediments. Marine Pollution Bulletin, 117 (1-2), pp. 161-170. https://doi.org/10.1016/j.marpolbul.2017.01.050

[9] Costa, M.P.F.; Novo, E.M.L.M.; Telmer, K.H. 2013: Spatial and temporal variability of light attenuation in large rivers of the Amazon. Hydrobiologia, 702 (1), pp. 171-190. https://doi.org/10.1007/s1 0750-012-1319-2

[10] Hassan, M.A.; Church, M.; Yan, Y.; Slaymaker, O. 2010: Spatial and temporal variation of in-reach suspended sediment dynamics along the mainstem of Changjiang (Yangze River), China. Water Resources Research, 46 (11), 1-14. https://doi.org/10.1029/2010WR009228

[11] Xue, Z.; Liu, J.P.; Ge, Q. 2011: Changes in hydrology and sediment delivery of the Mekong River in the last 50 years: connection to damming, monsoon, and ENSO. Earth Surface Processes \& Landforms, 36 (3), pp. 296-308. https://doi.org/10.1002/esp.2036

[12] Lobera, G.; Batalla, R.J.; Verica, D.; LópezTarazón, J.A., Tena, A. 2016: Sediment transport in two Mediterranean regulated rivers. Science of the Total Environment, 540, pp. 101-113. https://doi.org/10.1016/j.scitotenv.2015.08.018

[13] Wang, H.; Wu, X.; Bi, N.; Li, S.; Yuan, P.; Wang, A.; Syvitski, J.P.M.; Saito, Y.; Yang, Z.; Liu, S.; Nittrouer, J. 2017: Impacts of the dam-orientated water-sediment regulation scheme on the lower reaches and delta of the Yellow River (Huanghe): a review. Global and Planetary Change, 157, pp. 93-113. https://doi.org/10.1016/i.gloplacha.2017.08.005

[14] Ward, P.J.; Balen, R.T.V.; Verstraeten, G.; Renssen, H.; Vandenberghe, J. 2009: The impact of land use and climate change on late Holocene and future suspended sediment yield of the Meuse catchment. Geomorphology, 103 (3), pp. 389-400. https://doi.org/10.1016/i.geomorph.2008.07.006

[15] Bussi, G.; Dadson, S.J.; Prudhomme, C.; Whitehead, P.G. 2016: Modelling the future impacts of climate and land-use change on suspended sediment transport in the River Thames (UK). Journal of Hydrology, 542, pp. 357-372. htps://doi.org/10.1016/j.jhydrol.2016.09.010

[16] Dai, Z.; Fagherazzi, S.; Mei, X.; Gao, J. 2016: Decline in suspended sediment concentration delivered by the Changjiang (Yangze) River into the East China Sea between 1956 and 2013. Geomorphology, 268, pp. 123132. https://doi.org/10.1016/j.geomorph.2016.06.009

[17] Donnelly, T.W. 1993: Impoundment of rivers: sediment regime and its effect on benthos. Aquatic Conservation Marine \& Freshwater Ecosystems, 3 (4), pp. 331-342. https://doi.org/10.1002/aqc.3270030407

[18] Mikhailov, V.N.; Isupova, M.V. 2012: Sediment regime and morphological processes in the Hong Ha (Red River) mouth area. Water Resources, 39 (5), pp. 497-513. https://doi.org/10.1134/S0097807812050041

[19] Bonacci, O.; Tadić, Z.; Trninić, D. 1992: Effects of dams and reservoirs on the hydrological characteristics of the lower Drava River. River Research \& Applications, 7 (4), pp. 349-357. https://doi.org/10.1002/rrr.3450070405 
[20] Bonacci, O.; Oskoruš, D. 2010: The changes in the lower Drava river water level, discharge and suspended sediment regime. Environmental Earth Sciences, 59, pp. 1661-1670. https://doi.org/10.1007/s12665-0090148-8

[21] Tadić, L.; Brleković, T. 2019: Hydrological characteristics of the Drava River in Croatia. The Drava River Environmental Problems and Solutions. Lóczy, D (ed). Springer Geography Series, pp. 79-90.

[22] Bonacci, O.; Oskoruš, D. 2019: Human impacts on water regime. The Drava River Environmental Problems and Solutions. Lóczy D (ed). Springer Geography Series, pp. 125-137.

[23] Tamás, E.A. 2019: Sediment Transport of the Drava River. The Drava River Environmental Problems and Solutions. Lóczy D (ed). Springer Geography Series, pp. 91-103.

[24] Bonacci, O.; Trninić, D.; Roje-Bonacci, T. 2008: Analysis of the water temperature regime of the Danube and its tributaries in Croatia. Hydrological Processes, 22 (7), pp. 1014-1021. https://doi.org/10.1002/hyp.6975

[25] Garbrecht, J.; Fernandez, G.P. 1994: Visualization of trends and fluctuations in climatic records. JAWRA Journal of the American Water Resources Association, 30 (2), pp. 297-306. https://doi.org/10.1111/j.17521688.1994.tb03292.x

[26] Basarin, B.; Lukić, T.; Pavić, D.; Wilby, R.L. 2016: Trends and multi-annual variability of water temperatures in the river Danube, Serbia. Hydrological Processes, 30 (18), pp. 3315-3329. https://doi.org/10.1002/hyp. 10863

[27] Jain, S.K. 2008: Development of integrated discharge and sediment rating relation using a compound neural network. Journal of Hydrologic Engineering, 13 (3), pp. 124-131. https://doi.org/10.1061/(ASCE)10840699(2008)13:3(124)

[28] Liu, Q.J.; Shi, Z.H.; Fang, N.F.; Zhu, H.D.; Ai, L. 2013: Modeling the daily suspended sediment concentration in a hyperconcentrated river on the Loess Plateau, China, using the Wavelet-ANN approach. Geomorphology, 186, pp. 181-190. https://doi.org/10.1016/.geomorph.2013.01.012

[29] Kişi, Ö.; Zounematkermani, M. 2016: Suspended sediment modeling using neuro-fuzzy embedded fuzzy cmeans clustering technique. Water Resources Management, 30, pp. 1-16. https://doi.org/10.1007/s11269016-1405-8

[30] Rajaee, T.; Mirbagheri, S.A.; Zounemat-Kermani, M.; Nourani, V. 2009: Daily suspended sediment concentration simulation using ANN and neuro-fuzzy models. Science of the Total Environment, 407, pp. 4916-4927. https://doi.org/10.1016/j. scitotenv.2009.05.016

[31] Zhu, S.; Heddam, S.; Nyarko, E.K.; Hadzima-Nyarko, M.; Piccolroaz, S.; Wu, S. 2019: Modeling daily water temperature for rivers: comparison between adaptive neuro-fuzzy inference systems and artificial neural networks models. Environmental Science and Pollution Research, 26, pp. 402-420. https://doi.org/10.1007/s11356-018-3650-2

[32] Levi, B.G. 2008: Trends in the hydrology of the western US bear the imprint of manmade climate change. Physics Today, 61, pp. 16-18. https://doi.org/10.1063/1.2911164

[33] Bonacci, O. 2010: Analiza nizova srednjih dnevnih temperature zraka u Hrvatskoj. Građevinar, 62(9), pp. 781791. (in Croatian)

[34] Bonacci, O. 2010: Increase of mean annual surface air temperature in the Western Balkans during last 30 years. Vodoprivreda, 44, pp. 75-89.

[35] Bonacci, O.; Trninić, D.; Roje Bonacci, T. 2008: Analysis of the water temperature regime of the Danube and its tributaries in Croatia. Hydrological Processes, 22, pp. 1014-1021. https://doi.org/10.1002/hyp.6975

[36] Kişi, Ö. 2010: River suspended sediment concentration modeling using a neural differential evolution approach. Journal of Hydrology, 389, pp. 227-235. https://doi.org/10.1016/j.jhydrol.2010.06.003

[37] Kaveh, K.; Duc Bui, M.; Rutschmann, P. 2017: A comparative study of three different learning algorithms applied to ANFIS for predicting daily suspended sediment concentration. International Journal of Sediment Research, 32(3), pp. 340-350. https://doi.org/10.1016/j.jisrc.2017.03.007

[38] Ouellet-Proulx, S.; St-Hilaire, A.; Courtenay, S.C.; Haralampides, K.A. 2015: Estimation of suspended sediment concentration in the Saint John River using rating curves and a machine learning approach. Hydrological Sciences Journal, 61, pp. 1847-1860. https://doi.org/10.1080/02626667.2015.1051982

Please cite this article as:

Zhu, S.; Bonacci, O.; Oskoruš, D.: Assessing sediment regime alteration of the lower Drava River, Electronic Journal of the Faculty of Civil Engineering Osijek-e-GFOS, 2019, 19, pp. 1-12, https://doi.org/10.13167/2019.19.1 